\title{
Laporan Kasus Berbasis Bukti: Pedoman Skrining Populasi dengan Risiko Tinggi Talasemia
}

Nur Melani Sari, Irene Arini, Nur Suryawan, Susi Susanah, Lelani Reniarti, Harry Raspati, Ponpon Idjradinata Departemen Ilmu Kesehatan Anak Fakultas Kedokteran Universitas Padjadjaran/RSUP Dr. Hasan Sadikin, Bandung

Latar belakang. Talasemia merupakan penyakit keturunan akibat kelainan sel darah merah yang belum dapat disembuhkan, tetapi dapat dicegah. Berbagai studi memperlihatkan bahwa program pencegahan melalui skrining talasemia jauh lebih menguntungkan dibandingkan pengobatan. Skrining dapat dilakukan melalui berbagai metode, di antaranya skrining populasi umum dan populasi khusus. Sampai saat ini belum ada pedoman skrining khusus pada populasi dengan risiko tinggi.

Tujuan. Mengumpulkan bukti ilmiah mengenai validitas, manfaat, dan rekomendasi metode skrining keluarga (cascade family screening) pada penyandang talasemia.

Metode. Penelusuran pustaka secara daring lewat Pubmed Clinical Queries, Cochrane Library, dan Google Scholar.

Hasil. Didapatkan tiga artikel studi potong lintang yang berhubungan dengan pertanyaan klinis penelitian. Ketiga penelitian tersebut mempraktikan skrining kaskade pada anggota keluarga pasien talasemia- $\beta$ mayor dalam tiga generasi. Studi pertama (Ansari, dkk) menunjukkan 62,2\% anggota keluarga yang diskrining merupakan pembawa sifat talasemia beta. Studi kedua (Gorakshakar, dkk) menunjukkan angka pembawa sifat sebesar 21,9\%. Studi ketiga (Baig, dkk) menunjukkan angka pembawa sifat sebesar $44,4 \%$. Angka ini lebih besar dari frekuensi pembawa sifat talasemia dari populasi umum sebesar 5-8\%.

Kesimpulan. Skrining kaskade merupakan pilihan yang efektif dan praktikal dibandingkan dengan skrining populasi pada negaranegara dengan keterbatasan biaya dan sumber daya fasilitas kesehatan. Sari Pediatri 2020;21(5):322-28

Kata kunci: risiko tinggi, skrining, talasemia

\section{Evidence Based Case Report: Thalassemia Screening Guidelines for High- Risk Population}

Nur Melani Sari, Irene Arini, Nur Suryawan, Susi Susanah, Lelani Reniarti, Harry Raspati, Ponpon Idjradinata

Background. Thalassemia is a heredity disease due to erythrocyte abnormality; incurable but preventable. Many studies prove that thalassemia screening as prevention program is much more beneficial than treatment. Screening may be done through many methods including general population and specific (high-risk) population screening through cascade screening, a mechanism for identifying people at risk for a genetic condition by a process of systematic family tracing.

Objective. To outline the available evidence on the clinical validity and utility of cascade screening for thalassemia, while emphasizing the availability, usefulness, and recommendation.

Methods. An online literature search using Pubmed Clinical Queries, Cochrane Library, and Google Scholar.

Results. There were 3 cross sectional studies related to clinical question in this study (level of evidence 2). All three studies performed cascade screening method to three generation family of beta thalassemia major patients. The first study (Ansari, et al.) showed $62,2 \%$ of family members were positive for beta thalassemia trait. The second study (Gorakshakar, et al.) showed the number of beta thalassemia trait from screening are $21,9 \%$. While from the third study (Baig, et al.) showed the number are 44,4\%. These results are higher than thalassemia trait frequency from general population $(5-8 \%)$.

Conclusion. Cascade screening is an effective and practical choice compared to population screening in countries with budget and health facility source limitations. Sari Pediatri 2020;21(5):322-28

Keywords: high-risk, screening, thalassemia

Alamat korespondensi: Nur Melani Sari. Departemen Ilmu Kesehatan Anak Fakultas Kedokteran UNPAD/RSUP Dr Hasan Sadikin Bandung, Gedung Kenanga Lantai 3, Jl. Pasteur no. 38 Bandung. 
Nur Melani Sari dkk: Laporan kasus berbasis bukti: pedoman skrining populasi dengan risiko tinggi talasemia

$\mathrm{T}$

alasemia merupakan penyakit keturunan (kelainan genetik) akibat kelainan pembentukan rantai globin- $\alpha$ atau $\beta$ sebagai komponen hemoglobin utama. ${ }^{1}$ Sekitar 70.000 bayi dilahirkan dengan $\beta$-talasemia di seluruh dunia setiap tahun. ${ }^{2}$ Indonesia merupakan salah satu negara yang termasuk dalam sabuk talasemia dunia, yaitu negara dengan frekuensi gen (angka pembawa sifat) talasemia yang tinggi. Berdasarkan data YTI dan POPTI tahun 2014, hasil skrining masyarakat umum dari tahun 2008-2017 menunjukkan angka pembawa sifat sebesar 5,8\%; sedangkan skrining pada keluarga talasemia tahun 2009-2017 menunjukkan angka pembawa sifat sebesar $28,61 \%{ }^{3}$

Pembiayaan kesehatan untuk tatalaksana talasemia menempati posisi ke- 5 diantara penyakit tidak menular setelah penyakit jantung, kanker, ginjal, dan stroke; sebesar 376 milyar rupiah pada bulan September 2017, dengan jumlah kunjungan di tahun yang sama mencapai 420.393 pasien. Beban biaya rawat inap talasemia merupakan yang tertinggi dari kelompok penyakit tidak menular. ${ }^{3} \beta$-talasemia mayor menyebabkan anemia berat sehingga penderitanya bergantung pada transfusi darah. Transfusi berulang dapat menyebabkan kelebihan zat besi dan berujung pada sirosis hati dan kardiomiopati. Terapi kelasi besi digunakan untuk meningkatkan ekskresi zat besi yang memperpanjang usia individu dengan talasemia. ${ }^{4}$

Sampai saat ini, talasemia belum dapat disembuhkan, namun dapat dicegah. Berbagai studi memperlihatkan bahwa program pencegahan talasemia jauh lebih menguntungkan dibandingkan pengobatan. Berdasarkan pertimbangan tersebut, program pengelolaan penyakit talasemia seharusnya lebih ditujukan pada pencegahan kelahiran pasien talasemia mayor dengan melakukan skrining/penjaringan dan deteksi dini populasi yang beresiko. Akan tetapi, belum ada pedoman skrining khusus pada populasi dengan risiko tinggi talasemia. Oleh karena itu, ada kebutuhan yang jelas untuk pedoman skrining yang akurat dan sesuai kondisi Indonesia dengan populasi yang besar. Telaah kritis ini bertujuan untuk mencari tahu skrining talasemia pada populasi dengan risiko tinggi talasemia yang akan berpengaruh pada tatalaksana selanjutnya.

\section{Kasus}

Seorang anak laki-laki berusia 4 tahun dengan keluhan pucat sejak 3 hari sebelum masuk rumah sakit. Pasien baru didiagnosis talasemia pada usia 3 tahun, kini rutin kontrol teratur di poli hematologi RSHS dan mendapat transfusi darah merah setiap 1 bulan. Riwayat keluhan serupa di keluarga yaitu sepupu pasien, seorang anak perempuan berusia 4 bulan mendapatkan transfusi darah merah sebanyak 1 kali. Keluarga pasien sebelumnya belum pernah melakukan skrining talasemia.

Pada pemeriksaan fisik didapatkan perawakan pendek (berat badan $15 \mathrm{~kg}$, tinggi badan $94 \mathrm{~cm}$, lingkar lengan atas $12,5 \mathrm{~cm}, \mathrm{BB} / \mathrm{U}$ normal, $\mathrm{TB} / \mathrm{U}<-2 \mathrm{SD}, \mathrm{BB} /$ TB normal). Pasien tampak pucat, konjungtiva anemis dan lien teraba schuffner II. Pemeriksaan fisik lain dalam batas normal. Pemeriksaan laboratorium menunjukkan anemia $\left(\mathrm{Hb} 7,2 \mathrm{gr} / \mathrm{dL}\right.$, Ht $22 \%$, leukosit $6170 / \mathrm{mm}^{3}$,

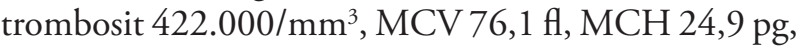
eritrosit 2,89 juta/ $/ \mathrm{mm}^{3}$ ).

Keluarga pasien dalam 3 generasi kemudian dikumpulkan dan diberikan edukasi mengenai talasemia Pada kasus ini, 19 anggota keluarga memenuhi kriteria skrining (usia $>18$ tahun). Dari jumlah ini, $13 \mathrm{di}$ antaranya menunjukkan gambaran anemia hipokromik mikrositer (MCV $<75 \mathrm{fl}$ dan $\mathrm{MCH}<25 \mathrm{pg}$ ) dan melanjutkan pemeriksaan elektroforesa ( 4 orang). Dari

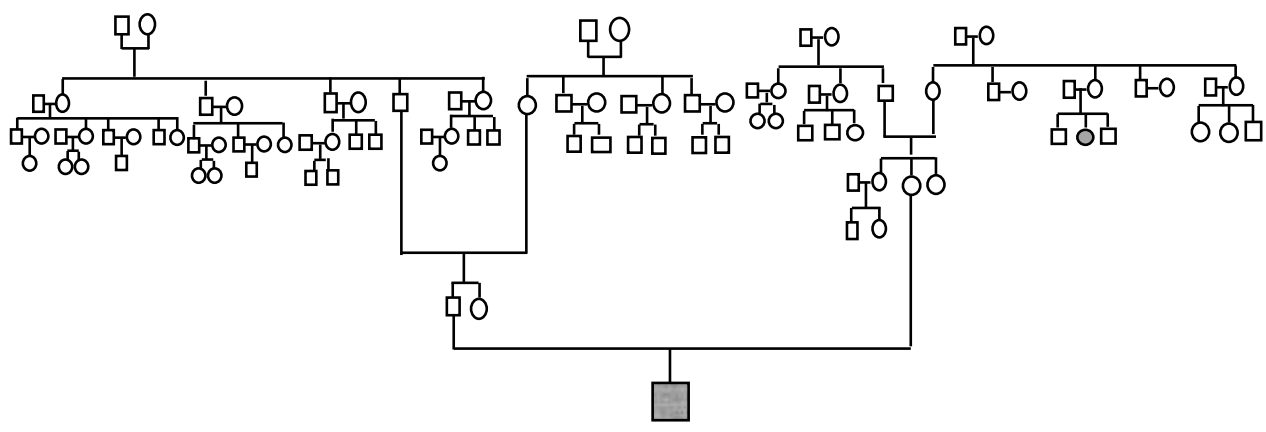

Sari Pediatri, Vol. 21, No. 5, Februari 2020 
jumlah tersebut, 2 di antaranya merupakan pembawa sifat talasemia (cut off point $\mathrm{HbA} 23,5 \%$ ).

\section{Pertanyaan klinis}

Berdasarkan ilustrasi kasus, pertanyaan klinis spada studi ini adalah sebagai berikut: "Bagaiaman pedoman skrining pada populasi dengan risiko tinggi talasemia di Indonesia?". Rumusan pertanyaan klinis tertera pada Tabel 1.

\section{Metode penelusuran literatur}

Prosedur pencarian pustaka dilakukan secara daring menggunakan instrumen pencari Pubmed Clinical Queries, Cochrane Library, dan Google Scholar. Kata kunci yang digunakan adalah "cascade", "extended family", "screening", "guideline", "identification", "population", "high", "risk", "thalassemia", menggunakan batasan penelitian dengan telaah sistematik, metaanalisis, uji coba klinis, laporan kasus, potong lintang, atau kohort.

\section{Hasil penelusuran literatur}

Melalui metode penelusuran dengan kriteria di atas, didapatkan total 30 artikel. Selanjutnya dilakukan skrining judul dan abstrak untuk menentukan artikel yang relevan dengan masalah yang telah dipaparkan sebelumnya. Dari proses ini didapatkan tidak didapatkan penelitian RCT, meta-analisis, atau systematic review; 3 studi potong lintang yang ditemukan selanjutnya ditelaah secara kritis (Tabel 2).

Kami melakukan telaah secara kritis pada 3 artikel yang telah melewati proses seleksi (Tabel 3). Proses ini dilakukan menggunakan formulir telaah kritis untuk studi potong lintang dari Joanna Briggs Institute tahun $2017 .^{8}$

Tabel 1. Rumusan pertanyaan klinis

\begin{tabular}{|c|c|c|c|c|}
\hline PICO & P Patient/Population & $\begin{array}{c}\mathrm{I} \\
\text { Intervention/indicator }\end{array}$ & C Comparison/Control & O Outcome \\
\hline & $\begin{array}{l}\text { Keluarga anak dengan } \\
\text { talasemia }\end{array}$ & $\begin{array}{l}\text { Cascade screening, extended } \\
\text { family screening }\end{array}$ & Skrining populasi & $\begin{array}{c}\text { Pembawa sifat } \\
\text { talasemia }\end{array}$ \\
\hline Aspek klinis & \multicolumn{4}{|c|}{ Skrining penyakit } \\
\hline Tipe studi & \multicolumn{4}{|c|}{ Telaah sistematik, metaanalasis, uji coba klinis, laporan kasus, potong lintang, kohort } \\
\hline
\end{tabular}

Tabel 2. Judul literatur terpilih

\begin{tabular}{|c|c|c|}
\hline & Judul & Jenis studi \\
\hline $\begin{array}{l}\text { Ansari } \mathrm{dkk}^{5} \\
(2012)\end{array}$ & $\begin{array}{l}\text { Screening immediate family members for carrier identification and } \\
\text { counseling: A cost-effective and practical approach }\end{array}$ & Potong lintang studi \\
\hline $\begin{array}{l}\text { Gorakshakar dkk } \\
(2009)\end{array}$ & $\begin{array}{l}\text { Cascade screening for } \beta \text {-thalassemia: A practical approach for identifying } \\
\text { and counseling carriers in India }\end{array}$ & Potong lintang studi \\
\hline $\begin{array}{l}\text { Baig } \mathrm{dkk}^{7} \\
(2008)\end{array}$ & $\begin{array}{l}\text { Prevention of } \beta \text {-Thalassemia in a Large Pakistani Family through Cascade } \\
\text { Testing }\end{array}$ & Potong lintang studi \\
\hline
\end{tabular}

Tabel 3. Hasil telaah kritis studi

\begin{tabular}{lccc}
\hline & $\begin{array}{c}\text { Ansari dkk } \\
(2012)\end{array}$ & $\begin{array}{c}\text { Gorakshakar dkk }^{6} \\
(2009)^{6}\end{array}$ & $\begin{array}{c}\text { Baig dkk }^{7} \\
(2008)\end{array}$ \\
\hline Apakah kriteria inklusi sampel didefinisikan dengan jelas? & Ya & Ya & Ya \\
Apakah subyek dan setting penelitian dideskripsikan dengan rinci? & Ya & Ya & Ya \\
Apakah paparan faktor risiko diukur secara valid dan reliable? & Ya & Ya & Ya \\
Apakah digunakan kriteria standar untuk menentukan kondisi sampel? & Ya & Ya & Ya \\
Apakah dilakukan identifikasi konfounding? & Tidak & Tidak & Tidak \\
Apakah strategi untuk mengatasi konfounding dijabarkan? & Tidak & Tidak & Tidak \\
Apakah hasil luaran diukur secara valid dan reliable? & Ya & Ya & Ya \\
Apakah analisis statistik yang sesuai digunakan? & Ya & Ya & Ya \\
\hline
\end{tabular}


Nur Melani Sari dkk: Laporan kasus berbasis bukti: pedoman skrining populasi dengan risiko tinggi talasemia

Tabel 4. Desain dan karakteristik studi

\begin{tabular}{|c|c|c|c|}
\hline Literatur & Sampel & Kelebihan & Kelemahan \\
\hline $\begin{array}{l}\text { Ansari dkk } \\
(2012)\end{array}$ & $\begin{array}{l}188 \text { saudara kandung } \\
\text { dari } 100 \text { pasien } \\
\text { talasemia }\end{array}$ & $\begin{array}{l}\text { Skrining awal dengan mendeteksi kadar } \\
\mathrm{Hb} \text {, MCV, dan } \mathrm{MCH} \text {; dilanjutkan } \\
\text { dengan pemeriksaan elektroforesa } \mathrm{Hb} \\
\text { pada pasien dengan } \mathrm{MCV} \text { dan } \mathrm{MCH} \\
\text { yang rendah. } \\
\text { Pembawa sifat talasemia didefinisikan } \\
\text { bila kadar HbA2 3,5-7\%. }\end{array}$ & $\begin{array}{l}\text { Tes baku emas talasemia } \\
\text { (elektroforesa } \mathrm{Hb} \text { ) tidak } \\
\text { dilakukan pada semua sampel } \\
\text { dalam penelitian. }\end{array}$ \\
\hline $\begin{array}{l}\text { Gorakshakar } \\
\mathrm{dkk}^{6}(2009)\end{array}$ & $\begin{array}{l}691 \text { individu dari } 44 \\
\text { keluarga besar pasien } \\
\text { talasemia beta mayor }\end{array}$ & $\begin{array}{l}\text { Skrining kaskade dengan baku emas } \\
\text { dilakukan pada kelompok risiko tinggi }\end{array}$ & $\begin{array}{l}\text { Tidak menelaah lebih lanjut } \\
\text { sampel dengan anemia } \\
\text { hipokromik mikrositer dengan } \\
\text { hasil elektroforesa Hb yang } \\
\text { normal }\end{array}$ \\
\hline $\begin{array}{l}\text { Baig dkk } \\
(2008)\end{array}$ & $\begin{array}{l}27 \text { individu dari } 1 \\
\text { keluarga besar pasien } \\
\text { talasemia beta mayor }\end{array}$ & $\begin{array}{l}\text { Skrining kaskade dengan baku emas } \\
\text { dilakukan pada seluruh sampel. } \\
\text { Pemeriksaan amplification refractory } \\
\text { mutation system dengan PCR juga } \\
\text { dilakukan untuk mengidentifikasi } \\
\text { mutasi spesifik }\end{array}$ & $\begin{array}{l}\text { Skrining hanya dilakukan pada } \\
\text { satu keluarga besar dari satu } \\
\text { pasien talasemia beta mayor } \\
\text { (kasus indeks) }\end{array}$ \\
\hline
\end{tabular}

\section{Pembahasan}

\section{Desain dan karakteristik studi}

Desain dan karakteristik studi dari ketiga artikel yang ditelaah tertera pada Tabel 4.

\section{Skrining talasemia}

Program skrining preventif untuk mengidentifikasi karier digunakan oleh banyak negara dengan tingkat talasemia yang tinggi. Berbagai pendekatan yang digunakan adalah edukasi tentang penyakit talasemia pada masyarakat, skrining populasi berisiko tinggi, skrining keluarga besar (skrining kaskade), konseling genetika pranikah, dan diagnosis pranatal. ${ }^{9-13}$ Negaranegara, seperti Cyprus, Italia, Inggris, Yunani, Iran, Iran, Turki, Sri Lanka, Cina, Tunisia, Thailand, dan Malaysia memiliki program skrining dan diagnostik pranatal yang baik. Dengan program skrining dan diagnosis pranatal, Cyprus, Italia dan Yunani telah $100 \%$ berhasil dan prevalensi kelahiran talasemia $\beta$ homozigot sekarang ada di angka nol. ${ }^{5}$

\section{Skrining premarital}

Pemerintah Cyprus dan Iran menetapkan peraturan wajib skrining premarital untuk pasangan yang akan menikah. ${ }^{11,14}$ Di Iran, indeks eritrosit calon mempelai pria diperiksa terlebih dahulu, bila hasilnya mencurigakan, baru calon mempelai wanita diperiksa. Bila keduanya mencurigakan, dilakukan pemeriksaan elektroforesis hemoglobin, dan bila positif karier maka dilakukan konseling genetik. Setelah mendapatkan konseling genetik, pasangan diberikan kebebasan untuk menentukan pilihan. Bila pasangan yang berisiko memilih untuk melanjutkan pernikahan, diagnosis pranatal menjadi opsi yang dapat dipilih selanjutnya sebelum memiliki anak. Apabila hasil konsepsi terdiagnosis thalassemia mayor maka aborsi terapeutik menjadi pilihan jika usia janin $<16$ minggu. ${ }^{14}$

\section{Skrining populasi umum secara volunteer}

Skrining voluntary dapat dilakukan pada populasi anak atau remaja. Colah $\mathrm{dkk}^{15}$ melakukan skrining pada 5682 anak sekolah menengah, 153 anak ditemukan sebagai karier, konseling dilakukan pada 71 anak. Setelah rentang waktu 20 tahun, 41 anak dapat dihubungi kembali. Tidak satupun mengungkapkan status karier atau menguji pasangannya. Satu pasangan memiliki anak talasamia. Dari hasil ini disimpulkan bahwa skrining anak sekolah menengah dengan konseling satu kali tidak cukup untuk membuat dampak.

\section{Skrining populasi risiko tinggi}

Skrining populasi berisiko tinggi dilakukan pada keluarga 


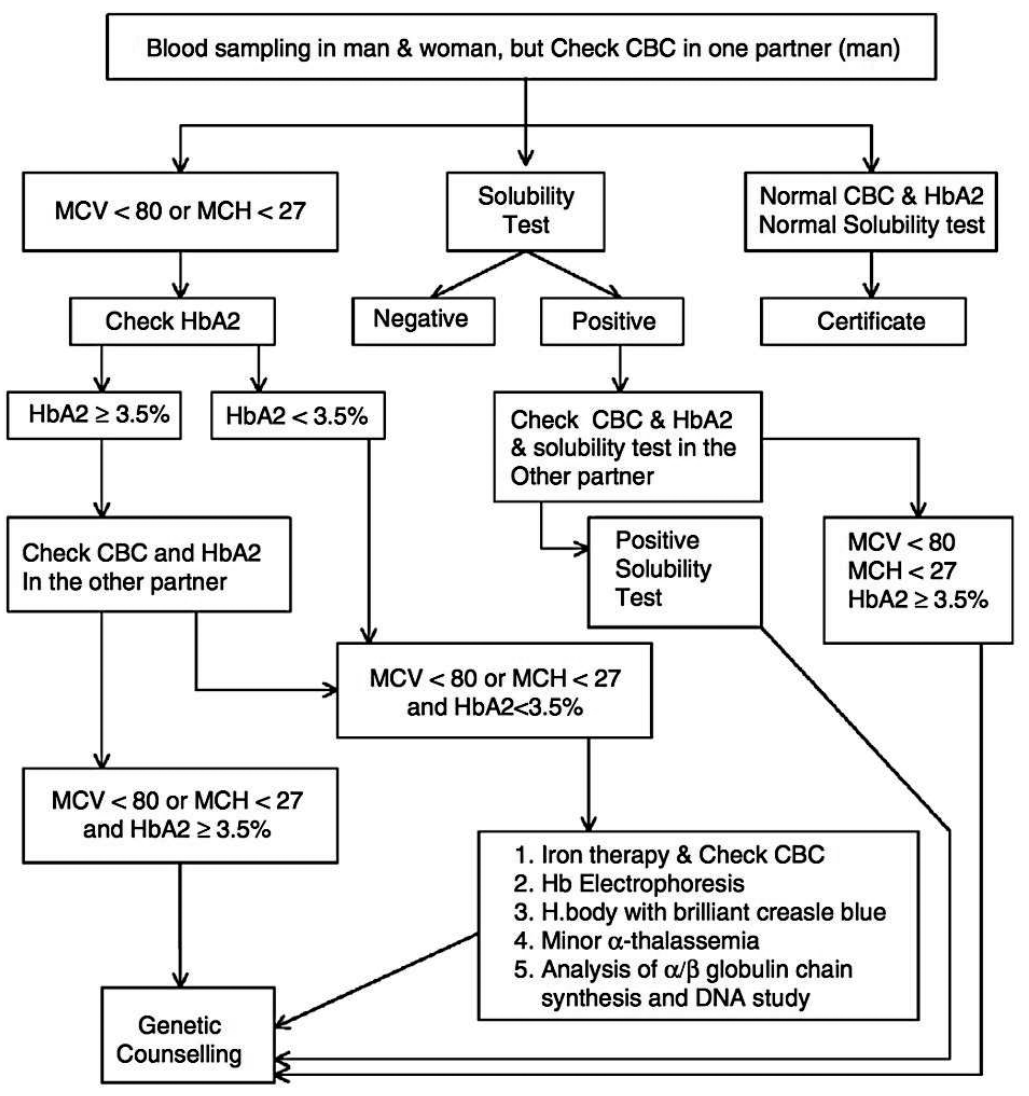

Gambar 1. Alur skrining talasemia di Iran Sumber: Karimi $\mathrm{M}^{14}$

pasien talasemia (kasus indeks). Skrining kaskade/keluarga besar (extended family) merupakan pilihan skrining yang baik dengan efisiensi biaya. Ahmed $\mathrm{dkk}^{16}$ menemukan bahwa menggunakan pendekatan ini mengidentifikasi 31\% karier di dalam keluarga di Pakistan. Oleh karena itu, dalam konteks keterbatasan sumber daya dan anggaran yang terbatas, skrining dapat berfokus pada saudara kandung pasien thalasaemia yang teridentifikasi dengan metode skrining kaskade. ${ }^{5}$

\section{Teknik dan tahapan skrining talasemia}

Beberapa prosedur telah diusulkan untuk skrining pembawa thalassemia. Metodelogi yang paling sering digunakan dalam seleksi awal individu yang berisiko menjadi karier adalah penentuan mean corpuscular volume (MCV) dan mean corpuscular haemoglobin $(\mathrm{MCH})$ (Gambar 2). Hasil positif pada tes skrining ini lebih lanjut akan diperiksakan kuantitatif HbA2, yang merupakan pemeriksan untuk mengidentifikasi $\beta$-talasemia heterozigot. ${ }^{10,11}$
Pasien thalassemia selalu mengalami anemia hipokrom ( $\mathrm{MCH}<26 \mathrm{pg}$ ) dan mikrositik (MCV $<75$ $\mathrm{fL}$ ), karenanya kedua kelainan ini tepat digunakan untuk pemeriksaan awal karier thalassemia. Kemungkinan anemia mikrositik akibat defisiensi besi harus disingkirkan melalui pemeriksaan porfirin eritrosit bebas, feritin serum, atau kadar besi serum, dengan total iron-binding capacity. ${ }^{10,11}$ Alur skrining identifikasi karier rekomendasi The Thalassemia International Federation (2013) mengikuti alur pada Gambar 3. ${ }^{9}$

\section{Pemeriksaan nilai indeks eritrosit}

Galanello menunjukkan bahwa pasien talasemia $\alpha$, talasemia $\beta$, dan $\mathrm{Hb}$ Lepore semuanya menunjukkan nilai $\mathrm{MCV}<78 \mathrm{fL}$ dan $\mathrm{MCH}<27$ pg, yang mengindikasikan bahwa kedua nilai tersebut dapat digunakan untuk uji saring awal. Indeks red cell distribution width (RDW) adalah indeks terbaik karena memberikan sensitivitas dan spesifisitas antara $90-100 \%$ untuk membedakan anemia zat besi dari talasemia. ${ }^{?}$ 
Nur Melani Sari dkk: Laporan kasus berbasis bukti: pedoman skrining populasi dengan risiko tinggi talasemia

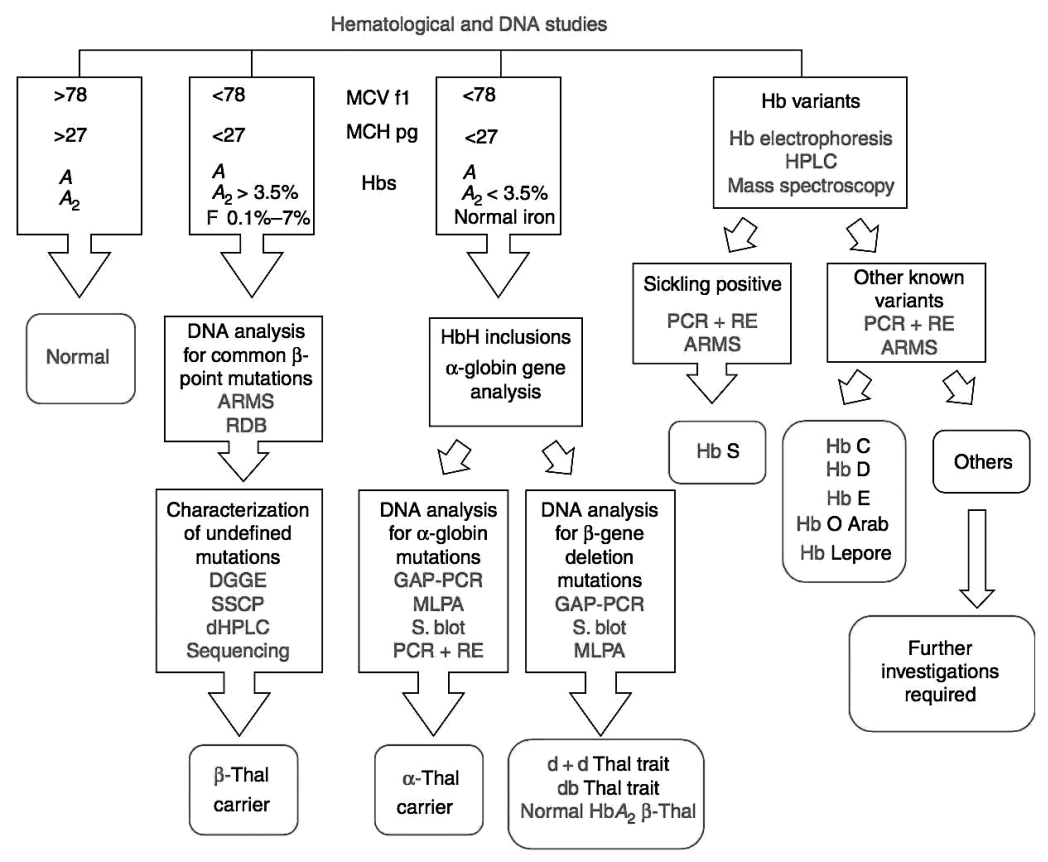

Gambar 2. Alur skrining thalassemia di Sardinia Sumber: Cao $\mathrm{A}^{11}$

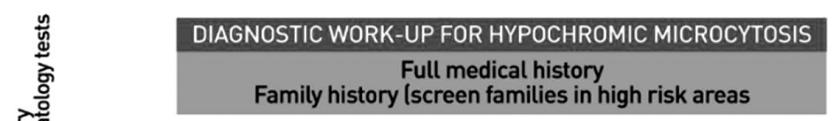

Complete blood cell count with erythrocyte indices (use an automated blood cell counter) Blood smear/BCB staining

$$
+\downarrow
$$

Low MCV $(<80 \mathrm{fl}) \pm \quad$ Consider other causes

Low $\mathrm{MCH}(<27 \mathrm{pg}) \quad$ of anemia

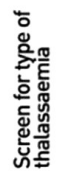

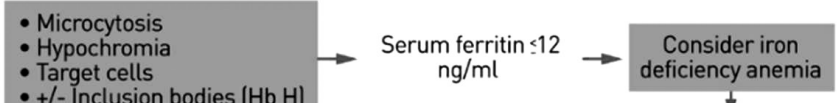

- +/- Inclusion bodies $(\mathrm{Hb} \mathrm{H})$

|

Serum ferritin $>12 \mathrm{ng} / \mathrm{mL}$

Adequate iron supplement for 3 months

$$
\downarrow
$$

Hb electrophoresis \& HPLC

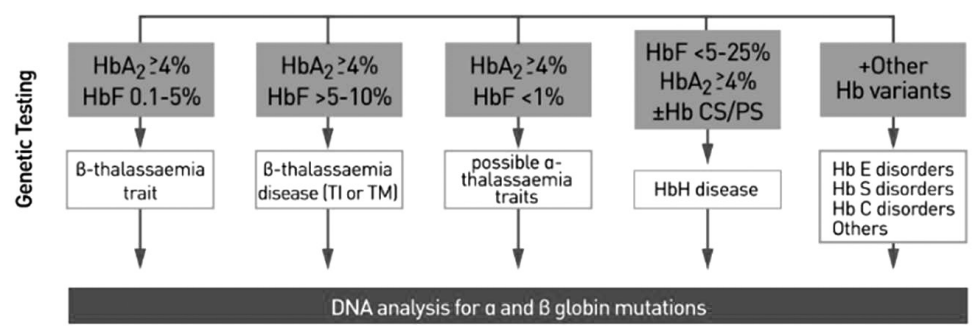

Gambar 3. Alur skrining the thalassemia international federation Sumber: Gallanelo ${ }^{9}$ 
Nur Melani Sari dkk: Laporan kasus berbasis bukti: pedoman skrining populasi dengan risiko tinggi talasemia

\section{Elektroforesis hemoglobin}

Peningkatan kadar $\mathrm{HbA}_{2}$ merupakan baku emas dalam menegakkan diagnosis karier talasemia. Subjek yang positif dalam skrining awal dengan nilai indeks eritrosit dikonfirmasi dengan penilaian kadar $\mathrm{HbA}_{2}$. Beberapa metode dapat digunakan, seperti kromatografi mikrokolom (microcolumn chromatography), highperformance liquid chromatography (HPLC), dan capillary iso-electrofocusing. Diagnosis ditegakkan bila kadar $\mathrm{HbA} 2>3,5 \%$.

\section{Analisis DNA}

Analisis DNA untuk mengetahui mutasi spesifik, tetapi semua pemeriksaan ini cukup mahal. ${ }^{9}$

\section{Kesimpulan}

Indonesia sampai dengan saat ini belum memiliki pedoman pasti untuk skrining talasemia terutama pada anak. Sebagai salah satu negara dengan insidensi dan beban talasemia yang cukup tinggi, Indonesia perlu memulai skrining talasemia untuk membantu menurunkan angka insidensi talasemia mayor. Beberapa studi menyimpulkan, skrining kaskade merupakan salah satu cara efektif dan praktikal yang dapat diterapkan di negara-negara dengan keterbatasan biaya dan fasilitas kesehatan seperti Indonesia.

\section{Daftar pustaka}

1. Payandeh M, Rahimi Z, Zare ME, Kansestani AN, Gohardehi F, Hashemian H. The prevalence of anemia and hemoglobinopathies in the hematologic clinics of the Kermanshah Province, Western Iran. Int J Hematol Oncol Stem Cell Res 2014;8:33-7.

2. Majeed T, Akter MA, Nayaar U. Frequency of $\beta$-thalassemia trait in families of thalassemia major patients, lahore. J Ayub Med Coll Abbottabad 2013;25:3-4.

3. Kementerian Kesehatan Republik Indonesia. Hari thalasemia sedunia 2018 : bersama untuk masa depan yang lebih baik.
2018 [cited 2019 Mar 19]. Jakarta: Kemkes 2018.h.1-10.

4. Galanello R, Origa R. Beta-thalassemia. Orphanet J Rare Dis 2010;5:11.

5. Ansari SH, Baig N, Shamsi TS, Saif-ur-Rechman. Screening immediate family members for carrier identification and counseling: A cost-effective and practical approach. J Pak Med Assoc 2012;62:1314-8.

6. Gorakshakar A, Colah R. Cascade Screening for $\beta$-thalassaemia: A practical approach for identifying and counselling carriers in India. Indian J Community Med 2009;34:354-6.

7. Baig SM, Din MA, Hassan H. Prevention of $\beta$-Thalassemia in a large Pakistani family through cascade testing. Community Genet 2008;11:68-70.

8. Joanna Briggs Institute. Critical appraisal tools. Diunduh pada 17 September 2019. Didapat dari: https://joannabriggs. org/critical_appraisal_tools.

9. Galanello R. Screening and diagnosis for haemoglobin disorders. Diakses pada 20 Februari 2020. Didapat dari: https:// www.ncbi.nlm.nih.gov/books/NBK190467/.

10. Chatterjee T, Chakravarty A, Chakravarty S. Population screening and prevention strategies for thalassemias and other hemoglobinopathies of Eastern India: Experience of 18,166 cases. Hemoglobin 2015;39:384-8.

11. Cao A, Kan YW. The prevention of thalassemia. Cold spring Harb Perspect Med 2013;3:a011775.

12. Nishad A, Premawardhena A. Parental Awareness and Cascade Screening of Thalassaemia in Sri Lanka. Hematol Transf Int Jour 2017;5:1-3.

13. Lavee O, Kidson-Gerber G. Antenatal haemoglobinopathy screening: Patterns within a large obstetric service. Working towards a standard of care. Obs Med 2015;8:184-9.

14. Karimi M, Jamalian N, Yarmohammadi H, Askarnejad A, Afrasiabi A, dan Hashemi A. Premarital screening for b-thalassaemia in Southern Iran: options for improving the programme. J Med Screen 2007;14:62-66.

15. Colah R, Thomas M, Mayekar P. Assessing the impact of screening and counseling high school children for $\beta$-thalassaemia in India. J Med Screen 2007;14:158.

16. Ahmed S, Saleem M, Modell B, Petrou M. Screening extended families for genetic haemoglobin disorders in Pakistan. N Engl J Med 2002;347:1162-8. 